\title{
Studies on Preparation of Protein and Beta Carotene Rich Guava (Psidium guajava) Fruitbar, cv. Allahabad Safeda
}

\author{
Pottapengera Prasanth* and Saket Mishra
}

Department of Horticulture, Sam Higginbottom University of Agriculture, Technology and Sciences, Naini Agricultural Institute, Allahabad - 211007, (U.P) India

*Corresponding author

\begin{tabular}{|c|c|}
\hline \multicolumn{2}{|r|}{ A B S T R A C T } \\
\hline & \multirow{5}{*}{$\begin{array}{l}\text { Guava bar fortified with carrot puree and different dry fruit powder like cashew, } \\
\text { almond, peanut with an aim to produce protein and } \beta \text {-carotene enriched Guava } \\
\text { fruit bar. The treatments consist of different blends of guava pulp and carrot puree } \\
\text { and different dry fruit powder were evaluated for Physico-chemical and sensory } \\
\text { characteristics and shelf life in ambient conditions of storage. The study revealed } \\
\text { that guava bar blended with peanut had increased protein content as much as } 0.46 \\
\text { to } 3.25 \text {. The evaluation for other parameters, like Moisture, Total soluble solids, } \\
\text { Titratable acidity, pH, Ascorbic acid, Reducing sugar, Total sugar, } \beta \text {-carotene, } \\
\text { protein were done up to } 90 \text { days at monthly intervals. The Moisture, TSS, } \\
\text { Titratable acidity and total sugars increased from storage period of } 90 \text { days, where } \\
\text { as there is a slight decline in the parameters like pH, ascorbic acid, } \beta \text {-carotene, } \\
\text { Protein, Reducing sugar from } 60 \text { days to } 90 \text { days of storage. The fruit bar recipe } \\
\text { with } 80 \% \text { guava pulp, } 19 \% \text { Carrot puree and } 1 \% \text { peanut recorded highest sensory } \\
\text { score. }\end{array}$} \\
\hline Keywords & \\
\hline $\begin{array}{l}\text { Fortification, } \\
\beta \text {-carotene, } \\
\text { protein, Guava } \\
\text { fruit bar, Fruit } \\
\text { leather. }\end{array}$ & \\
\hline Article I & \\
\hline $\begin{array}{l}\text { Accepted: } \\
\text { 23 June } 2017 \\
\text { Available Online: } \\
10 \text { Julv } 2017\end{array}$ & \\
\hline
\end{tabular}

\section{Introduction}

Guava (Psidiumguajava) 'Apple of tropics' is one of the most common fruit in India which belongs to the family Myrtaceae. It is native to tropical parts of America and the only member of Myrtaceae cultivated worldwide.

The total area under guava in India is $268,000.2$ ha with the production of 3667.9 MT/HT (NHB, 2015). Major guava producing states in India are Bihar, Maharashtra, Uttar Pradesh, Karnataka, West Bengal, Andhra Pradesh, Gujarat and Madhya Pradesh. Guavas are an excellent source of essential minerals such as calcium, phosphorus, magnesium, and iron. They are also a good source of many vitamins like niacin, thiamine, riboflavin, besides being an exceptional source of vitamin $\mathrm{C}$, presenting up to 4 times the amount found in oranges (US Department of Agriculture, 2009). Moreover, guavas are also a good source of natural antioxidants such as the polyphenols and carotenoids (Alothman et al., 2009). Polyphenol compounds are found in the peel (7.79\%) and pulp (2.62\%), contributing significantly to the high antioxidant capacity of guava (Jimenez-Escrig et al., 2001). 


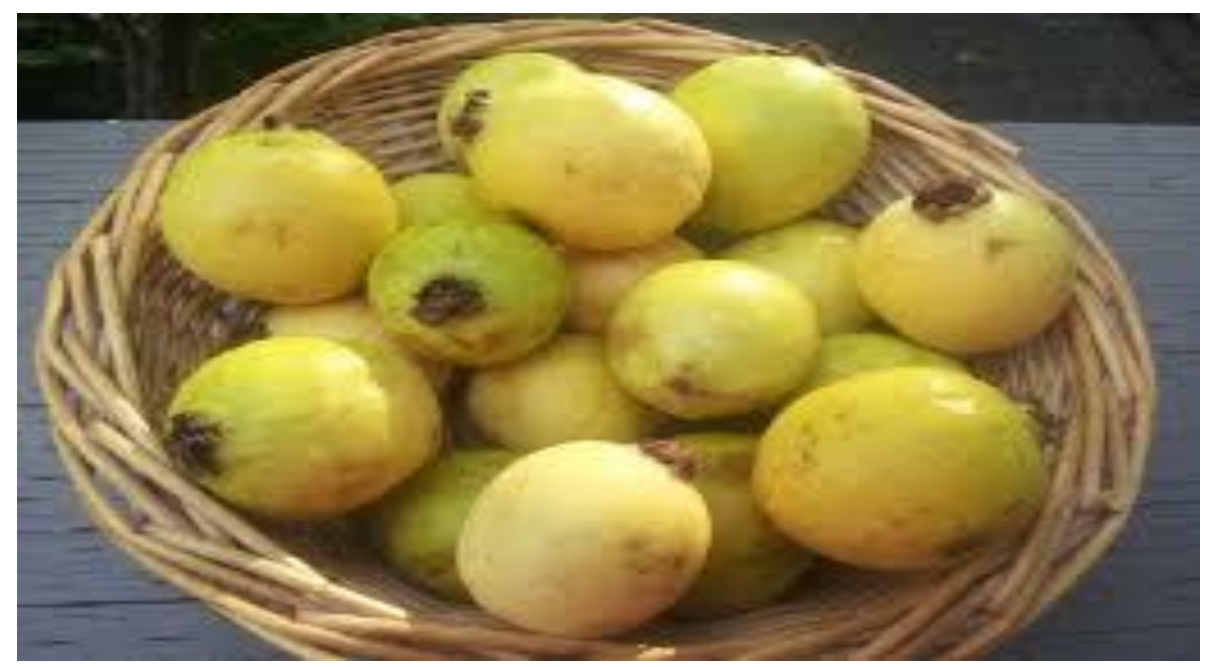

Fresh fruit of Allahabad safeda variety

The fresh fruits have limited shelf life (6-8 days) which limits strategic selling of fresh guava fruit. Under these conditions guava growers fail to get attractive returns and nearly 20-25 percent of produce goes as ravage (Nidhi and Matthew, 2006). Therefore, it is necessary to utilize the fruit for making different products like jam, jelly, nectar, pulp, cheese, canned fruit segments, ready-to-serve drink, squash, dried powder, ice cream, highly concentrated puree, candy, toffees, syrup, juice and concentrate, fruit bar or dehydrated products, as well as being used as an additive to other fruit juices or pulps (Jain and Asati, 2004) and (Kadam et al., 2012).

Fruit leathers or bars are dehydrated fruit based products. The destruction of original fruit structure by pureeing and restructuring in dehydrated sugar-acid- pectin gels called "fruit leathers" provide attractive, coloured products, on which research is enhanced nowa- days. Fruit leathers also allow left over ripe fruits to be preserved (Natalia et al., 2011). Dehydrated fruit processing is gaining importance now-a-days due to long shelf life, light weight, better handling during export and providing variety to the consumers. Fruit leathers are dried sheets of fruit pulp that have a soft, rubbery texture and sweet taste. They are produced by dehydrating of fruit puree into a leathery sheet (Raab and Oehler, 1999).

Cashew nut is a good source of protein and contains essential amino acids and contains 13 percent of dietary fibre. Cashew nut contains $(18 \mathrm{~g} / 100 \mathrm{~g})$ of protein (Manay et al., 1987).

\section{Treatment combination with details}

\begin{tabular}{|l|}
\hline T0 (Control) \\
\hline T1 90\%pulp + 9\% Carrot puree $+1 \%$ cashew \\
\hline T2 90\%pulp $+9 \%$ Carrot puree $+1 \%$ almond \\
\hline T3 90\%pulp $+9 \%$ Carrot puree $+1 \%$ peanut \\
\hline T4 80\%pulp $+19 \%$ Carrot puree $+1 \%$ cashew \\
\hline T5 80\%pulp $+19 \%$ Carrot puree $+1 \%$ almond \\
\hline T6 80\%pulp $+19 \%$ Carrot puree $+1 \%$ peanut \\
\hline T7 70\%pulp $+29 \%$ Carrot puree $+1 \%$ cashew \\
\hline T8 70\%pulp $+29 \%$ Carrot puree $+1 \%$ almond \\
\hline T9 70\%pulp $+29 \%$ Carrot puree $+1 \%$ peanut \\
\hline
\end{tabular}


Another protein Almond is characterized by having heart healthy fats. Almond has a high nutritional value and is a good source of dietary fibre 48 percent. Almond has protein (21 g/100 g) content (Ali jahanban, 2010). Peanut is one of the cheap sources of protein $(25 \mathrm{~g} / 100 \mathrm{~g})$ content.

The guava fruit contains negligible $\beta$-carotene content. Carrot (vegetable) exceedingly high in $\beta$-carotene is selected to blend with and fortify guava fruit bar. Consuming carrots are known to be good for the overall health and specially organs like the skin, eyes, digestive system and teeth. It contains 2546.6IU of vitamin-A per one cup (228) of mashed carrot. So carrot puree is used for enhancing the vit-A content of guava fruit bar. Protein and fat are available in dry fruits which could be utilized for enrichment of product. Future addition of carrot not only enriches $\beta$ carotene, but also gives better colour to the fruit bar/leather.

\section{Materials and Methods}

The present investigation was carried at the Post Harvest Laboratory, Department of Horticulture, SHUATS Allahabad during 2016-17. Fruits of Allahabad Safeda variety were freshly procured from the local market of Rambagh, Allahabad during winter season.

Similarly, carrots of local variety were obtained from local market. Fruits and dry fruits are subjected to physico-chemical tests before utilizing for the product. Guava fruit bar is prepared from the fruits following the methodology given by (Jain, 2007) Treatments comprising of 10 varying blends were designed and the experiment was laid using Completely Randomized Design (Mahony, 1985). The prepared products were evaluated for the physico-chemical, sensory parameters and shelf life studies at ambient condition.

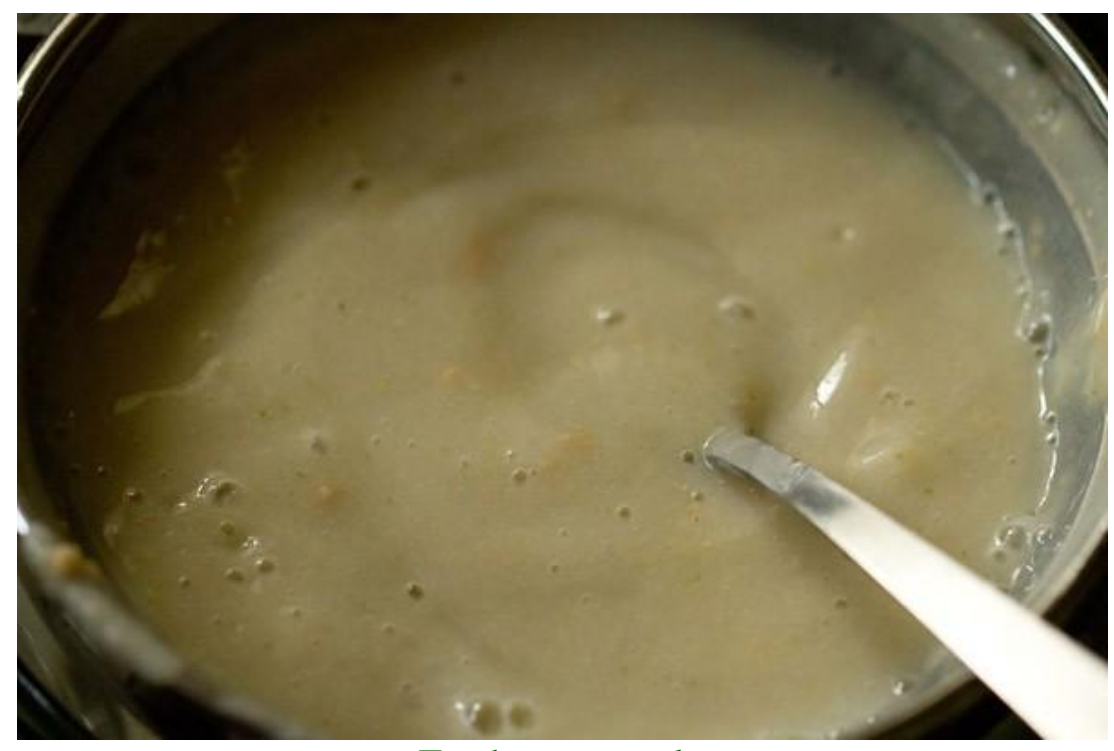

Fresh guava pulp

Total soluble solids (T.S.S., expressed in ${ }^{\circ} \mathrm{B}$ ) and $\mathrm{pH}$ of the product were determined using hand refractometer and digital $\mathrm{pH}$ meter, respectively. The Titratable Acidity was determined by titrimetric method, whereas ascorbic acid (mg/100g) was determined by titrating the product against 2, 6dichlorophenol indophenol indicator (A.O.A.C, 1990). Sugars were estimated by Lane and Eynon's method (1923) in terms of 
reducing and total sugars. $\beta$-carotene were determined using spectrophotometer. Protein estimation was carried out by the Lowery method. The guava bar prepared from fresh fruits and which is stored over a period of 90 days were subjected to organoleptic evaluation by a panel of five judges following hedonic rating tests as described by Ranganna (1991). The product was evaluated for colour, flavour, texture and overall acceptability. The characters with mean scores of 5 or more out of 9 marks were considered acceptable.

\section{Result and Discussion}

In the present investigation, possibilities were explored for preparation of fortified guava fruit bar blended with carrot puree and different dry fruit using different recipes.

\section{Physico-chemical properties of guava fruit bar}

The data should be presented in table 1 and figure 1 , showed maximum moisture $\%$ in the terms of treatment (T3) $(23.5 \%)$ at 90 days interval. Similar results have been reported by Aleem Zaker et al., (2012) In general there was an increase in moisture content in all fortified fruit bars with addition of carrot puree when compared to (T0) control.

Maximum TSS content was recorded in the treatment (T3), $\left(65.75^{\circ} \mathrm{Brix}\right)$ at 90 days interval. TSS increased in all the treatments during storage period. This might be due to addition of sugar, after drying TSS increased. The results of present investigation are in accordance with the findings of Baramanray et al., (1995)

There were significant differences amongst the Titratable acidity up to 60 days of storage, however they became non significant after 90 days. Maximum acidity is recorded in treatment (T0) control, (1.2); at 90 days interval. Similarly the acidity in fruit bar was reduced by addition of carrot puree in different proportion. The results of present investigation are in accordance with the findings of Anju et al., (2014).

The maximum $\mathrm{pH}$ was recorded in treatment (T3) (4.35) at 90 days interval. As a result of increasing acidity, a significant decrease in $\mathrm{pH}$ of guava fruit bar was noticed. Similar results of $\mathrm{pH}$ were guava leathers by Babalola et al., (2002).

The data should be presented in table 2 and figure 2 showed maximum reducing sugars are recorded in the treatment $\left(\mathrm{T}_{6}\right),(16.53 \%)$, at 90 days interval was mainly due to the acid hydrolysis of sugars Karan Jalker et al., (2013). Maximum total sugars are recorded in the treatment (T6), (56.3\%) at 90 days interval, which was mainly due to increased concentration of protein in dry fruit and also due to conversion of insoluble polysaccharides and other carbohydrate polymers to soluble sugars (Teshome, 2010). The maximum ascorbic acid is recorded in the treatment (T0) control, (61.24 mg) at 90 days interval, where as there is a decline in the content of ascorbic acid in the fortified fruit bars Fennema (1996).

Maximum $\beta$-carotene was recorded in the treatment $\left(\mathrm{T}_{8}\right),(1179.1 \mu \mathrm{g})$ at 90 days interval. Maximum protein was recorded in the treatment (T3) (3.25g) at 90 days interval. The increase in protein content in fruit bar which was mainly due to addition of dry fruit having high protein content.

\section{Shelf-life studies of guava fruit bar}

The data pertaining to the organoleptic evaluation of the products over a period of 90 days has been represented in table 3. (T5) maximum colour (sensory score) was recorded in term of treatment (T5), (8.75) at 
90 days interval), while maximum texture (sensory score ) was recorded for 90 days in the terms of treatment (T5), (9.0). The maximum flavour(sensory score) was recorded for 90 days in the terms of treatment (T5), (9.0), while maximum taste (sensory score) was recorded for 90 days in the terms of treatment (T5), (8.5). The data indicated that the overall acceptability of guava fruit bar fell in the category of 'liked very much' the maximum overall acceptability (sensory score) was recorded at 90 days interval in the terms of treatment (T5), (9.2).

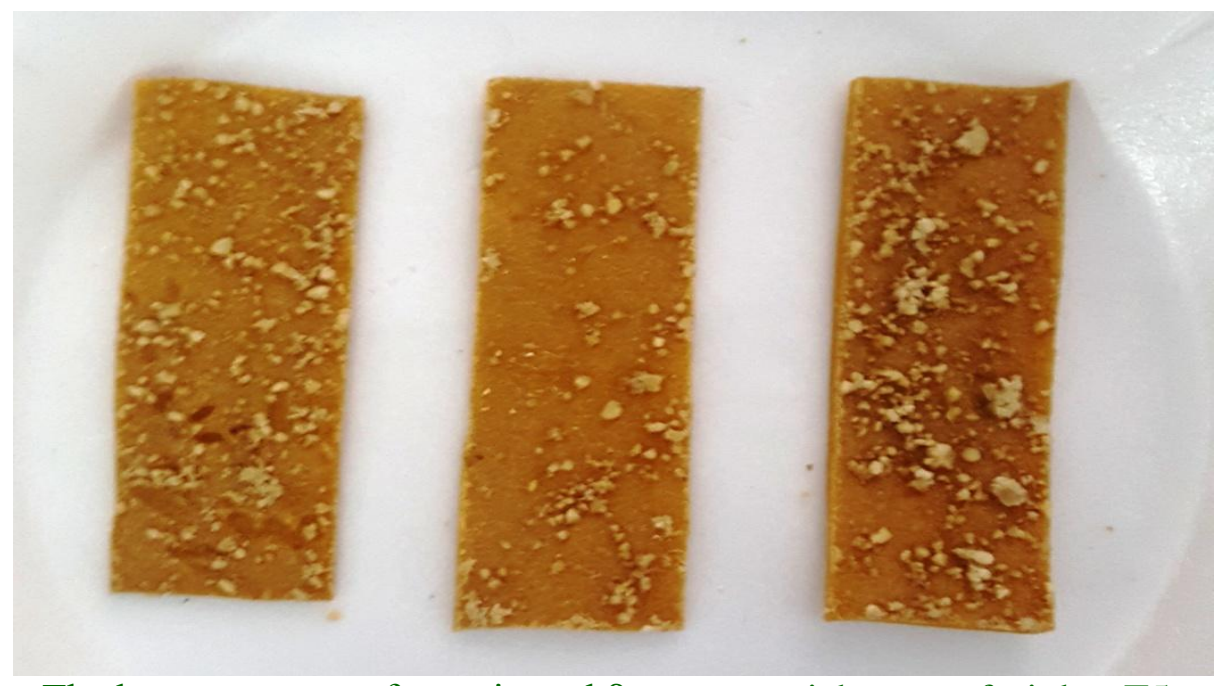

The best treatment of protein and $\beta$-carotene rich guava fruit bar T5

Table.1 Effect of different treatments on moisture, total soluble solids, titratable acidity, $\mathrm{pH}$ of Guava (Psidium guajava) fruit bar, cv. Allahabad safeda

\begin{tabular}{|c|c|c|c|c|}
\hline $\begin{array}{l}\text { Character } \\
\text { Treatments }\end{array}$ & $\begin{array}{c}\text { Moisture \% } 90 \\
\text { DAT }\end{array}$ & $\begin{array}{c}\text { TSS ( }{ }^{\circ} \text { Brix) } 90 \\
\text { DAT }\end{array}$ & $\begin{array}{c}\text { Titratable } \\
\text { acidity \% } \\
90 \text { DAT }\end{array}$ & $\begin{array}{c}\mathrm{pH} \\
90 \mathrm{DAT}\end{array}$ \\
\hline $\mathbf{T}_{\mathbf{0}}$ & 5.35 & 60.86 & 1.2 & 3.34 \\
\hline $\mathbf{T}_{1}$ & 23 & 64.86 & 0.95 & 4.14 \\
\hline $\mathbf{T}_{2}$ & 24.6 & 65.4 & 0.86 & 4.19 \\
\hline $\mathbf{T}_{3}$ & 25.5 & 65.75 & 0.86 & 4.35 \\
\hline $\mathbf{T}_{4}$ & 21.4 & 62.65 & 0.99 & 3.66 \\
\hline $\mathbf{T}_{5}$ & 21.8 & 62.7 & 0.96 & 3.73 \\
\hline$T_{6}$ & 22.7 & 63.63 & 0.96 & 3.85 \\
\hline $\mathbf{T}_{7}$ & 17.3 & 63.83 & 1.15 & 3.44 \\
\hline $\mathbf{T}_{8}$ & 18.2 & 64.33 & 1.1 & 4.05 \\
\hline T9 & 19.8 & 62.25 & 1.05 & 3.66 \\
\hline Mean & 36.3 & 115.68 & 1.83 & 6.98 \\
\hline Result & $\mathbf{S}$ & $\mathbf{S}$ & NS & $\mathbf{S}$ \\
\hline S. Ed. ( \pm$)$ & 0.100 & 0.059 & 0.241 & 0.275 \\
\hline $\begin{array}{l}\text { C. D. } \\
(P=0.05)\end{array}$ & 0.213 & 0.124 & 0.512 & 0.583 \\
\hline
\end{tabular}


Table.2 Effect of different treatments on reducing sugar, total sugar, ascorbic acid, $\beta$-carotene and protein of Guava (Psidium guajava) fruit bar, cv. Allahabad safeda

\begin{tabular}{|l|c|c|c|c|c|}
\hline $\begin{array}{l}\text { Character } \\
\text { Treatments }\end{array}$ & $\begin{array}{c}\text { Reducing } \\
\text { sugar \% } \\
\text { 90 DAT }\end{array}$ & $\begin{array}{c}\text { Total sugar \% } \\
\text { 90 DAT }\end{array}$ & $\begin{array}{c}\text { Ascorbic acid } \\
(\mathrm{mg} / 100 \mathrm{~g}) \\
\text { 90 DAT }\end{array}$ & $\begin{array}{c}\beta \text {-carotene } \\
\left(\mu \mathrm{g} 100 \mathrm{~g}^{-1}\right) \\
90 \mathrm{DAT}\end{array}$ & $\begin{array}{c}\text { Protein }(\mathrm{g}) \\
90 \text { DAT }\end{array}$ \\
\hline $\mathbf{T}_{\mathbf{0}}$ & 14.3 & 50.53 & $\mathbf{6 1 . 2 4}$ & 343.78 & 0.47 \\
\hline $\mathbf{T}_{\mathbf{1}}$ & 14.98 & 52.7 & 47.53 & 1173.88 & 2.62 \\
\hline $\mathbf{T}_{\mathbf{2}}$ & 13.61 & 51.14 & 46.31 & 1173.45 & 2.88 \\
\hline $\mathbf{T}_{\mathbf{3}}$ & 13.25 & 53.88 & 46.04 & 1172.4 & $\mathbf{3 . 2 5}$ \\
\hline $\mathbf{T}_{\mathbf{4}}$ & 16.05 & 52.2 & 52.55 & 1175 & 1.5 \\
\hline $\mathbf{T}_{\mathbf{5}}$ & $\mathbf{1 6 . 5 3}$ & 54.68 & 53.24 & 1173.5 & 2.12 \\
\hline $\mathbf{T}_{\mathbf{6}}$ & 14.05 & 51.86 & 55.82 & 1176.4 & 0.96 \\
\hline $\mathbf{T}_{\mathbf{7}}$ & 14.9 & 53.3 & 51.8 & $\mathbf{1 1 7 9 . 1}$ & 1.05 \\
\hline $\mathbf{T}_{\mathbf{8}}$ & 15.34 & $\mathbf{5 6 . 3}$ & 54.77 & 1172.3 & 1.3 \\
\hline T9 & 27.14 & 96.16 & 95.06 & 1985.11 & 3.37 \\
\hline Mean & $\mathbf{S}$ & $\mathbf{S}$ & $\mathbf{S}$ & $\mathbf{S}$ & $\mathbf{S}$ \\
\hline Result & 0.0024 & 0.0124 & 0.004 & 0.002 & 0.020 \\
\hline S. Ed. $( \pm)$ & 0.0052 & 0.0263 & 0.010 & 0.005 & 0.042 \\
\hline $\begin{array}{l}\text { C. D. } \\
(\mathbf{P}=\mathbf{0 . 0 5})\end{array}$ & & & & & \\
\hline
\end{tabular}

Table.3 Effect of different treatments on shelf life studies of Guava (Psidium guajava) fruit bar, cv. Allahabad safeda

\begin{tabular}{|c|c|c|c|c|c|}
\hline $\begin{array}{l}\text { Character } \\
\text { Treatments }\end{array}$ & $\begin{array}{l}\text { Colour } \\
\text { (Sensory } \\
\text { scores ) } \\
\text { 90DAT }\end{array}$ & $\begin{array}{c}\text { Texture } \\
\text { (Sensory } \\
\text { scores) } \\
\text { 90DAT }\end{array}$ & $\begin{array}{c}\text { Flavour } \\
\text { (Sensory } \\
\text { scores) } \\
\text { 90DAT }\end{array}$ & $\begin{array}{c}\text { Taste } \\
\text { (Sensory } \\
\text { scores) } \\
\text { 90DAT }\end{array}$ & $\begin{array}{c}\text { Overall acceptability } \\
\text { (Sensory scores) } \\
\text { 90DAT }\end{array}$ \\
\hline $\mathbf{T}_{0}$ & 5.09 & 6 & 6.55 & 5.25 & 6 \\
\hline $\mathbf{T}_{1}$ & 5.12 & 6.55 & 7.65 & 6.5 & 6.3 \\
\hline $\mathbf{T}_{2}$ & 7.63 & 7.5 & 7 & 7 & 6.55 \\
\hline $\mathbf{T}_{3}$ & 8.05 & 8.55 & 8.3 & 8.2 & 8.2 \\
\hline$T_{4}$ & 5.15 & 8.35 & 7 & 7.5 & 8 \\
\hline$T_{5}$ & 8.75 & 9 & 9 & 8.5 & 9.2 \\
\hline$T_{6}$ & 8.3 & 6.5 & 8 & 8.3 & 6.8 \\
\hline $\mathbf{T}_{7}$ & 7.5 & 6.8 & 7.2 & 7.2 & 7 \\
\hline $\mathbf{T}_{8}$ & 7.55 & 7.72 & 8 & 7 & 7.2 \\
\hline T9 & 5.28 & 6.45 & 7.5 & 8 & 6.8 \\
\hline Mean & 12.4 & 13.3 & 13.9 & 13.3 & 13.1 \\
\hline Result & $S$ & $\mathrm{~S}$ & $\mathbf{S}$ & $S$ & $\mathbf{S}$ \\
\hline S. Ed. $( \pm)$ & 0.74 & 0.74 & 0.76 & 0.78 & 0.74 \\
\hline $\begin{array}{l}\text { C. D. } \\
(\mathbf{P}=\mathbf{0 . 0 5})\end{array}$ & 1.58 & 1.58 & 1.62 & 1.66 & 1.58 \\
\hline
\end{tabular}


Fig.1 Effect of different treatments on moisture, total soluble solids, titratable acidity, $\mathrm{pH}$ of Guava (Psidium guajava) fruit bar, cv. Allahabad safeda

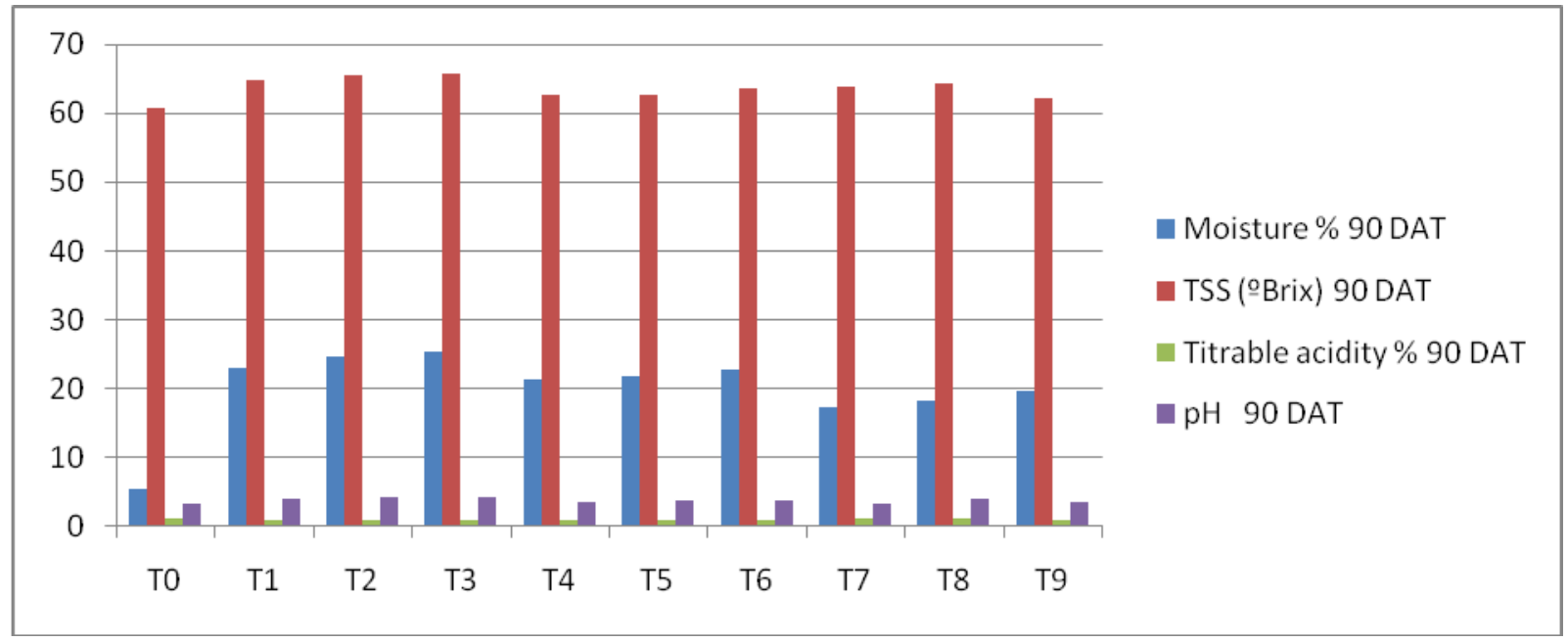

Fig.2 Effect of different treatments on reducing sugar, total sugar, ascorbic acid, $\beta$-carotene and protein of Guava (Psidium guajava) fruit bar, cv. Allahabad safeda

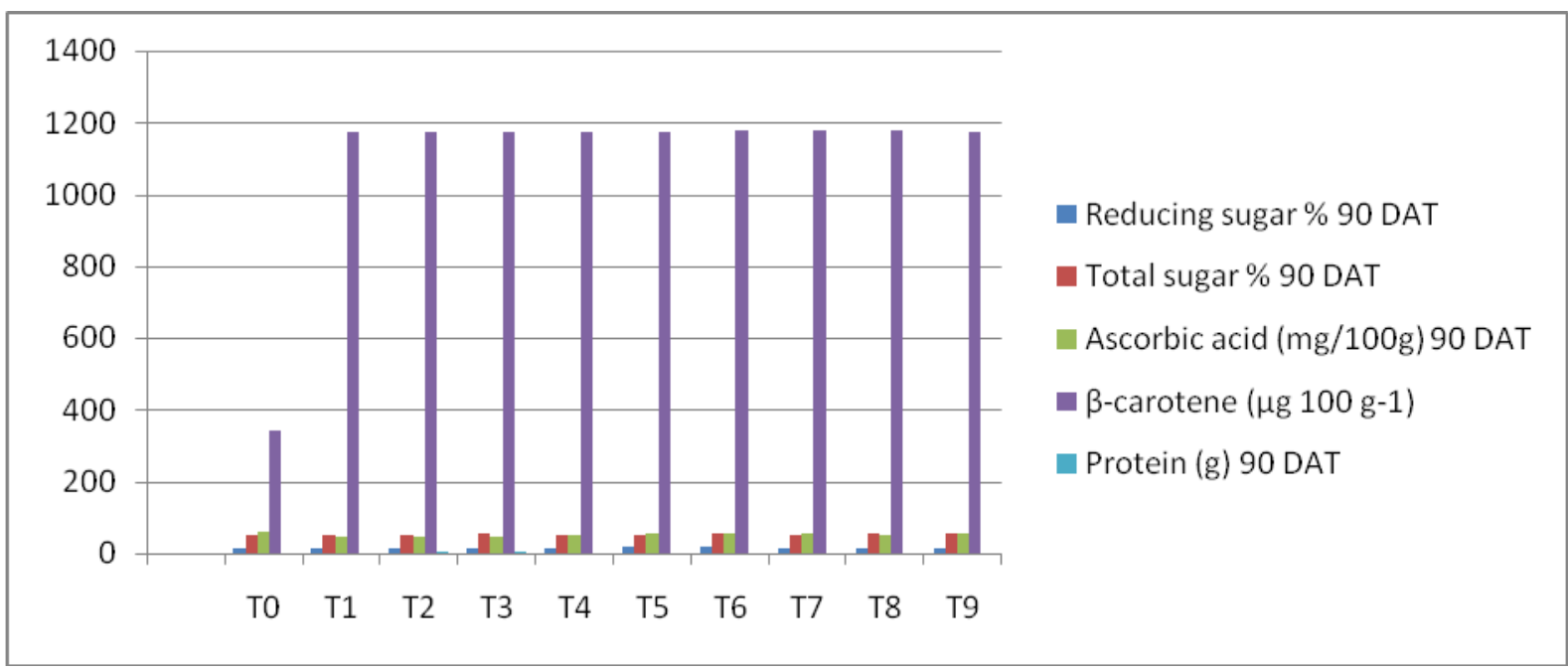

According to the study of physico-chemical parameters like, $\operatorname{TSS}\left(65.75^{\circ} \mathrm{Brix}\right)$, moisture $(23.5 \%)$ and protein $(3.25 \mathrm{~g})$ the best treatment is (T3) but as it does not secure good scores in the sensory evaluation conducted up to 90 days at monthly intervals, when compared with T5.

It is concluded from the present investigation that treatment T5 (80\%pulp $+19 \%$ Carrot puree $+1 \%$ almond $)$ with $\operatorname{TSS}\left(62.7^{\circ}\right.$ Brix $)$ was found most suitable and best treatment in terms of quality, sensory scores, and the quality of the product was remained acceptable up to 3 months (90 days) under ambient storage conditions.

\section{References}

Aleem Zaker, M.D, Genitha, T.R and S.I, Hashmi. 2012. Effects of defatted soy flour incorporation on physical, sensorial and nutritional properties of biscuits. J. Food 
Processing and Tech., 3(4): 1-4.

Ali Jahanban Esfahlan, A., Rashid Jameia, Rana, J.E. 2010. The importance of almond (Prunus amygdalus L.) and its by-products. Food Chem., 120: 349-360.

Alothman, M., Bhat, R., Karim, A.A. 2009. Antioxidant capacity and phenolic content of selected tropical fruits from Malaysia, extracted with different solvents. Food Chem., 115: 785-88.

Anju, B., Kumari, K.R., Anand, V. and Anjum, M.A. 2014. Preparation, quality evaluation and storage stability of peach-soy fruit leather. SAARC J. Agri., 12(1): 73-88.

AOAC. 1990. Approved methods of association of official analytical chemists. Washington D.C. U.S.A. 11: P- 240.

Babalola, S.O., Ashaye, O.A., Babalola, A.O. and Aina, J.O. 2002. Effect of cold temperature storage on the quality attributes of pawpaw and guava leathers. African J. Biotech., 1(2): 61-63.

Baramanray, A., Gupta, O.P. and Dhawan, S.S. 1995. Evaluation of guava (Psidium guajava L.) hybrid for making nectar., Haryana J. Hort. Sci.

Fennema, R. 1996. Food Chem., New York: Marcel Dekker. Inc.

Jain, P.K. and Asati, V.K. 2004. Evaluation of guava cultivars for pulp preparation.

Jain, P.K. and Nema, P.K. 2007. Processing of pulp of various cultivars of guava (Psidium guajava L.) for leather production. Agric. Eng. Int., Vol IX.

Jimenez-Escrig, A., Rincon, M., Pulido, R., Saura-Calixto, F. 2001. Guava fruit (Psidium guajava L.) as a new source of antioxidant dietary fiber. J. Agric. Food Chem., 49: 5489-93.
Kadam, D.M, Prathibha, K and Ramesh Kumar. 2012. Evaluatio of guava products quality. Int. J. Food Sci. Nutrition Engi., 2(1): 7-11.

Karanjalker, G.R., Singh, D.B. and Rajwade, V.B. 2013. Development and evaluation of protein enriched guava nectar blended with soymilk an Inter. Quarterly J. Life Sci., 8(2): 631-634.

Lane, J.H. and Eynon, L. 1923. Determination of reducing sugars by means of Fehling's solution with methylene blue as internal indicator. J. Soc. Chem. Industry, 42: 32-36.

Mahony, M.O. 1985. Sensory evaluation of food: statistical methods and procedures. Marcel Dekker. New York. 168-169.

Manay, et al. 2012. Sci. Nature, IJSN_Vol3(2), J/IJSN- 12-29.

Natalia, A., Q. Ruiz, S.M. Demarchi and S. A. Giner. 2011. Research on dehydrated fruit leathers: A Review. Journal of Food Sci. Technol., 41(6): 684-686.

National Horticulture Board Data Base. 2015. http://www.nhb.gov.in

Nidhi, C. and P. Matthew. 2006. Development of guava candies. J. Food Sci. Technol., 43(2): 210-212.

Raab, C. and Oehler, N. 1999. Making dried fruit leather. Fact Sheet, 232. Oregon State University Service, Tillamook, Ore, USA.

Ranganna, S. 1991. Handbook of Analysis and Quality Control for Fruits and vegetable Products. Tata McGraw Hill Publishing Company Limited, New Delhi.

Teshome, B. 2010. Effect of Processing on some quality attributes of mango (Mangifera indica) fruit leather [Electronic]. 146. Retrieved, Master of Science.

USDA (United States Dept of Agriculture). National Nutrient Database for Standard, Release 22, 2009.

\section{How to cite this article:}

Pottapengera Prasanth and Saket Mishra. 2017. Studies on Preparation of Protein and Beta Carotene Rich Guava (Psidium guajava) Fruitbar, cv. Allahabad Safeda. Int.J.Curr.Microbiol.App.Sci. 6(7): 2485-2492. doi: https://doi.org/10.20546/ijcmas.2017.607.293 